\title{
Young graduates are looking for jobs! Between education and the labor market
}

\author{
Naghi Dana-loana \\ Research Institute for Quality of Life \\ dananaghi@gmail.com
}

\begin{abstract}
The social inclusion on the labor market of a young graduate marks a decisive step in the process of transition to adulthood. Theoretically, completing a higher education level should increase the employment chances of a young person who has just entered within the labor market. in this regard, the paper aims to describe the situation of the young graduates in Romania, concerning: the extent to which education increases the chances of accessing the labor market, what statistics tell us about the situation of the youth in Romania and where do we stand at the European level, and also how the labor market inequalities are reproduced. From a broader view, this paper points out also the main challenges that youth face on the labor market, such as: the unlemployment and the precarious jobs, the spreading of the underemployment and the lack of jobs, the educational patterns and labor market changes, these are some topics that will be discussed. ${ }^{1}$
\end{abstract}

Keywords: young graduates, higher education, unemployment, labor market, underemployment.

Introduction: looking for the right job?

Within an ideal society, the transition from adolescence to adulthood is considered a normal and predictitibil route of life, which is carried on with the transition from school towards labor market. The outcome of the educational system can be measured by the capacity of a young graduate to develop himself professionally, meaning finding a job. However, the success of the educational process involves finding the right job, which gives the young the opportunity to achieve a desirable level of welfare for society. in this way, it becomes both a promoter of social change but also one of the reproduction of society. The operationalization of the concept "right job" refers to occupying a job according to the professional training (qualification, specialization), educational attainment (the last form of education and training) and professional experience (work experience). But in the context of increasing level education, being young graduate on the labor market nowadays, is not easy because of the slow economic recovery in 2012 and 2013 that caused a crisis of jobs. This reality has increased the competitiveness of labor, newly educated youth being forced to share fewer available jobs, but the same jobs for the employees with more experience than them. Thus we are facing a growing demand of jobs under the conditions of a more accentuated decrease labor supply. But discouraging youth on the labor market occurs from the insecurity and precarious jobs, too. Youth opportunities are limited: they are less selective, forced to accept jobs with low wages, under their level of training or give up looking for the right job. Therefore underemployment and unemployment are both key elements that characterize the labor market evolution and quality among the young people. The extension of the jobs crisis trend is globally reflected, the ILO report "Global Employment Trends for Youth 2013" considers the current generation of youth "a generation at risk" which is forced, to be less selective about the type of job they are prepared to accept, a tendency that was already evident before the crisis. Increasing numbers of youth are now turning to available part-time jobs or find themselves stuck in temporary employment." (ILO, 2013, p. 1). Another barrier that influence youth employability refers to the ability of higher education to provide appropriate skills. Structural changes in the labor market are a result of the mutual determination between occupational structure (supply and demand of labor, unemployment and underemployment, etc.) and the capacity of education to create opportunities for graduates on the labor market in terms of specialization and determining employability according to the qualification obtained. On the modern labor market, the option for higher education has become increasingly common and according to Beck is also a personal and an economic survival strategy because "the employment contexts are increasingly differentiated and with increased competition for jobs (Furlong \& Cartmel, 2007). Segregation of the professional trajectories of young people in the light of transition from college to work

1 This paper is made and published under the aegis of the Research Institute for Quality of Life, Romanian Academy as a part of programme co-funded by the European Union within the Operational Sectorial Programme for Human Resources Development through the project for Pluri and interdisciplinary in doctoral and post-doctoral programmes Project Code: POSDRU/159/1.5/S/141086 
started to individualize and differentiate increasingly more, making it more difficult to analyze the trends in the field of youth employment.

Summarizing it can be accepted the following hypothesis: the level of education determines the chances of accessing the labor market but it doesn't determine directly finding the right job, according to the level of education attained.

\section{Massification of higher education or mismatched skills?}

The success of a young higher education graduate on the labor market is a broad discussed topic both by policies and research studies aimed to describe the evolution of higher education and the labor market employability of graduates (Teichler, 2008). Both issues are complex and interrelated processes, their dynamics being very hard to identify. After more than 10 years, the Ministry of Youth and Sport launched the "National Strategy for Youth Policy 2014-2020". This defines the areas of intervention and establishes the target groups of youth policy. To enable a comparison at an European level, youth population is divided into age groups between $14-35$ years (14/15-19, 20-24, 25-29 and 30-34/35). for the field of "work and entrepreneurship", the strategy provides the following types of intervention: "unemployed and long term unemployed young people, youth caught up in forms of self-employment subsistence, youth who are neither employed nor enrolled in education or training forms (NEETs), youth involuntarily employed in temporary or part-time employment forms, youth workers with low wages and very low-income, young people engaged in informal employment forms, overqualified or underqualified youth."(MTS, 2013, p.9). The evaluation of the national higher education system has been the subject of some studies undertaken by stakeholders concerned about the amplitude of the phenomenon. in terms of institutional assessment, a functional analysis on higher education about "improving education and training is essential not only to fulfill the two goals of the EU2020 directly related to education (increasing the enrollment in higher education and reducing early school leavers)" but also for quality assurance. (World Bank, 2011). Here are analyzed the changes produced by Bologna system and the impact of tertiary education. Regarding the relationship between work and education, between 2005-2010 it was conducted a pilot study at national level: "Monitoring labor market insertion of graduates from public and private institutions of higher education: Graduates and Labor Market (APM)" (UEFISCDI, 2010, p.4). This is the first national project, which aimed the connection between studies and graduated young professional activity in order to increase institutional capacity for monitoring them. Also, it followed university graduates careers in order to a better match between study supply and employers requirements. The increasing "inflation of diplomas" represents one of the effects produced by "massification of higher education". However, the World Bank report, notes that "the analysis of registrations and the number of graduates is in fact the analysis of the number of certificates issued, not of the abilities and skills produced by this sector" (World Bank, 2011, p 28). However, achieving a qualification requires a formal recognition of the professional skills in a specific area. in other words qualification involves acquiring a specialization and its certification by diplomas. A study focused on the evolution of Romanian university qualifications makes an interesting analysis on the variation between the evolution of the number of students and types of specialization. The extension of the higher education system took place in Romania after 2000 and by the end of 2008 the number of students almost doubled. Private education and introduction of distance learning forms have influenced this growth and have led to an interdependent changes between occupational structure and educational system. (Sora, 2011). From the individual perspective (graduates) in terms of quality of training acquired during the years of professional training, a special focus is placed on the area of specialization, career choice motivation, specific skills, expectations, opportunities (Voicu, Tufiş, \& Voicu, 2010). The survey also says which are the most popular specializations on the labor market and makes an interesting analysis on the programs of study, topic which lead to three types of employment: according to the graduated specialization (sciences, engineering and veterinary medicine) in related fields (social and human sciences, economics) and in different areas. Thus specialization is an important criteria for the professional career and can determine a young graduate employability on the labor market. The importance of specialization as a measure of higher education quality is the ability of the followed study area in order to provide useful skills in the labor market.

\section{Young graduate on the labor market: being unemployed or being underemployed?}

Acquiring new social roles such as adulthood can be a difficult transition step, first of all because of the problems raised by youth age and because of their limited experience in the labor market: their social adaptation need by experimenting those new social roles along with the constantly desire of social learning and changing. Secondly because of the unpredictability and competitiveness on the labor market. To create an efficient human resource, the society invests in the human and social capital of youth in order to create them opportunities for accessing the labor market. It also ensures a 'grace' period through the time needed with their professional education and training. However the effort of the society may be inoperable 
in uncontrolled economic conditions and unpredictable labor market context. Thus special mechanisms are required to enhance institutional capacity on the labor market insertion of young people by creating new jobs. As a result of the technological progress, labor market dynamics develops a fast pace that puts pressure on the continuous training of the workforce but also increases the complexity of the work. Social change affects the occupational structure of the labor content and the professions specificity, which may cause serious changes to macro level. Thus occupational structure changes of the labor market are just a passing trend or it reflects the real market need? Why is there a higher demand than supply of jobs in certain activity fields? On one hand it relates to structural changes in the labor market and on the other with labor supply and demand processes which are similar to those of the market for goods and services. Labor market as a subsidiary economic market is running under the economical market. Hence the free market processes should be enriched with structural mechanisms to facilitate the transition of young people from school to work. It requires coordinated action between state, employers and education system, in order to increase investment in youth's social capital and to prevent the development of youth vulnerable categories. in this way those who are not admitted at universities won't experience marginalization by being permanently discouraged. (Petersen, A. C. \& Mortimer, 1994). An interesting study about the situation in Romania, which analyzes the ratio of monthly averages of unemployed graduates and the available jobs, shows that during the economic crisis "job offer was extremely low compared to the request from the graduates. The job offer for graduates decreased significantly (by $47.6 \%$ during the crisis) as well as the number of economic participants (32.9\%). Total demand of jobs increased by $8.7 \%$ while the request from the graduates was higher in 2010 with 2089 units compared to 2008. If the evolutionary trends of supply and demand of jobs for graduates were opposed in 2009 it is observable that the stock of graduates that remained without jobs was very high. "(Mocanu, 2012).

According to European and national policies, one of the major objectives is combating unemployment and increasing labor market insertion among young people, concomitantly with achieving the assumed European target, regarding the educational level of population. Actually, the social inclusion of graduates on the labor market requires a complex and a special social protection policies, the lack of data, directly from the source, being replaced by secondary analysis of data from the Household Labor Force Survey of the National Institute of Statistics, data from Eurostat and other national surveys.

However, in Romania, even if the educational level of the population increased, the share of occupancy decreased while increasing the unemployment rate1. This trend is also reflected among young population. The employment rate in Romania shows that young people aged between 30-34 years are the closest to the European level and they can be considered the age group that raises the fewest social problems in the labor market (the fourth quarter of 2013-76\%), while all the other age groups of youth, have been placed below the EU-28 values: in the same analyzed period young people within 15-19 years recorded the lowest employment rate $-7.5 \%$ and they are considered to be the most vulnerable category and also they have an increased risk of becoming NEETs (Lunsing, 2007). About 1 out of 3 young Romanians, aged between 20 and 24 years occupies a job. The employment rate for those aged between $25-29$ years old, in 2013 decreased (2000/75\% $2007 / 70 \% 2012 / 68 \%$ and the fourth quarter of 2013/66\%) but comparing with the previous two age groups, things are a little better. Youth unemployment is a phenomenon that provides reasons of concerns for the age group of 15-24 years (fourth quarter of 2013-33\%). Even if the unemployment rate decreases for the next category, underemployment represents a current problem for those aged between $20-24$ and also for $25-29$ years $(22.5 \%$ and $12 \%$ ), with high education (ISCED 5-6). From this perspective, higher education graduates represent a vulnerable group (Preoteasa, 2013). in this context, the main challenges that young people face in the labor market are: the unemployment and the precarious jobs, the spreading of the underemployment and the lack of jobs, the educational patterns and labor market changes. A feature of this category is the one that takes into account the specificity of occupations as well as the specialization. Young employees with higher education often occupy jobs under their educational level being in disagreement with their professional education and training. The phenomenon of underemployment in terms of qualification and quality of employment is found among vulnerable groups who present an increased social risk or who are in vulnerable situations on the labor market. (Zamfir, Stănescu, \& Briciu, 2010). Two categories are taken into account:

Recent graduates (high school or college).

Discriminated persons such as:

- Ethnic minorities

- Roma population

- People with disabilities

1 National Institute of Statistics (INS), Household Labor Force Survey (AMIGO) - employment rate by age and gender: www.insse.ro 
- Immigrants

- Women

- People who have been institutionalized, etc.

The underemployment refers to an inadequate employment situation which involves an employee and it is characterized by 3 specific circumstances: 1 . Over qualification or overeducation 2. Involuntary part-time work 3. Overstaffing or labor hoarding. (Bolino \& Feldman, 2000). "Overqualification or overeducation" refers to the specificity of qualifications that characterizes both training and experience level. These concepts describe the workforce with tertiary training (higher education, higher skills) and / or with a high level work experience engaged for some reasons in jobs that do not require such training or experience level. The quality of employment and the qualification of human resources call into question a better correlation of the skills provided by higher education on the labor market. The ILO report regarding to trends of youth employment in 2013 shows that "results suggest that two of the macro-level factors cause a sizeable part of skills mismatch development over time. A higher share of tertiary graduates increases the incidence of overeducation and decreases the incidence of undereducation. It appears that an increase in the number of tertiary graduates creates stronger competition and therefore increases the chances of overeducation." (ILO, 2013, p. 34). Thus, the mismatch between graduated specializations and market fields creates a stock of inadequate skills. Within the context of jobs crisis, generated by a too large request comparing with the available labor supply, it have been identified a number of risks at which the youth graduates are exposed on the labor market:

Individual risks:

- Precarious employment

- Skills alteration

- "Out-of-date" qualifications

- Low living standards

- Low wage

- Extending the period of financial dependency on parents

Social risks

- Long term underemployment / unemployment

- Inflation of graduates / field of study / specialization

- Jobs crisis.

- Affecting economic system (dysfunctional economy)

- Increasing dependency rate

- Demographic changes: the declining birth rate, nuptiality, number of marriages etc.

- Degradation of the population health

- Changes in family patterns

- Changes in youth's consumption behavior

- Poverty

- Social exclusion and marginalization

\section{References}

[1] Bolino, M., \& Feldman, D. (2000). The antecedents and consequences of underemployment among expatriates. Journal of Organizational Behavior, 21, 889-911.

[2] Furlong, A., \& Cartmel, F. (2007). Young People and Social Change. New Perspectives (Second Edi., p. 199). London: Open University Press.

[3] ILO. (2013). Global Employment Trends for Youth 2013 A generation at risk (p. 116). Geneva. Retrieved from http://www.ilo.org/wcmsp5/groups/public/---dgreports/---dcomm/documents/publication/wcms_212423.pdf 
[4] Lunsing, W. (2007). The Creation of the Social Category of NEET (Not in Education, Employment or Training): Do NEET Need This? Social Science Japan Journal, 10(1), 105-110. doi:10.1093/ssjj/jym016

[5] Mocanu, I. (2012). Occupation and Unemployment of Romanian Graduates during the current EconomicFinancial Crisis. Revista Română de Statistică, 353-359.

[6] MTS Ministerul Tineretului și Sportului. (2013). Strategia Naţională în domeniul politicii de tineret 2014-2020.

[7] Petersen, Anne C., \& Mortimer, J. T. (1994). Youth unemployment and society. Vasa (First Edit., p. 338). New York: Cambridge Univesity Press.

[8] Sora, A. (2011). The evolution of the Romanian higher education qualifications between 1968-2011. Bucharest: DOCIS

[9] Teichler, U. (2008). Diversification? Trends and explanations of the shape and size of higher education. Higher Education (Vol. 56, pp. 349-379). doi:10.1007/s10734-008-9122-8

[10] UEFISCDI. (2010). Report of implementation study for monitoring labor market insertion of higher education graduates.

[11] Voicu, B., Tufiș, C., \& Voicu, M. (2010). Recent graduates of higher education and their integration on the labor market.

[12] Zamfir, C., Stănescu, S., \& Briciu, C. (2010). Social inclusion policies in the economic crisis. Bucharest: Expert.

[13] World Bank. (2011). Functional analysis of the higher education sector in Romania. Retrieved from http://www.invatamant-superior.ro/wp-content/uploads/2013/08/Analiza-Functionala-a-Sectorului-InvatamantSuperior-in-Romania.pdf 